\title{
Spirits and Those Living in the Shadows: Migrants and a New National Family in Biutiful
}

Usando la noción de hauntology, expuesta por Jacques Derrida en su libro Specters of Marx, este trabajo analiza el film Biutiful (2010), dirigido por Alejandro González Iñárritu. González Iñárritu explora los "espectros" de la sociedad española mediante un diálogo con el cine de terror, en el que se elabora un vínculo entre la explotación y el sufrimiento de los inmigrantes actuales con el destino de los exiliados de la Guerra Civil. Asimismo, sugiere que nuestra relación con los marginados es realmente filial: tenemos que vivir y convivir con los "espectros" como miembros de una familia nacional. Al insertar la referencia al desenterramiento de las víctimas de la Guerra Civil, González Iñárritu sugiere que si la sociedad española quiere reconocer las atrocidades del pasado, no puede ignorar la situación de los inmigrantes actuales.

Alejandro González Iñárritu established himself as a director with a keen political and social engagement with his first three features, Amores Perros (2000), 21 Grams (2003), and Babel (2006). Working closely with a team, he became known for a unique style of multi-protagonist films and non-linear plots, pushing the genre to new heights (Deleyto \& Azcona xi-xii). ${ }^{2}$ However, his 2010 film Biutiful marked a break not only with scriptwriter Guillermo Arriaga, but also a departure from some of the trademark elements audiences had come to associate with Iñárritu - significantly, his fourth film featured a more straightforward plot that revolved in the main around a central protagonist. In spite of the shift in narrative style, key thematic elements were maintained, such as a preoccupation with mortality and the possibility of redemption through suffering. ${ }^{3}$ So, too, did the visual style developed by Iñárritu and cinematographer Rodrigo Prieto continue to impose what Justin Chang, in his Variety review, described as a "heaviness of spirit," and "a raw visual kineticism that imparts a rough, jagged quality to the narrative."

While the gritty realism continues, since his 2010 film, the director has focused on developing certain metaphysical gifts in his protagonists, as both Biutiful and the recent Oscar-winning Birdman (2014) attest. Birdman's first scene shows sixty-something Riggan (Michael Keaton) levitating in his underwear, an introduction to several unexpected and 
supernatural events which occur throughout the film. Biutiful features Uxbal (Javier Bardem), a medium, or vidente in Spanish. The subtleties of the words in English and Spanish highlight the different facets of Uxbal's ability. He mediates, and is a conduit or "go-between" amongst different groups of people or spheres of society, and even different planes of existence. Vidente, which comes from ver, emphasizes Uxbal's capacity to see what is hidden in the shadows, that which others are unable, or unwilling, to acknowledge. While Riggan's mind-bending powers dramatize Birdman's rumination on the ego, the metaphysical in Biutiful posits a space not only for self-understanding but also for understanding the Other. The gift of sight, to see and to be with the Other, is necessary for living a just life.

In this essay I shall discuss Biutiful in conjuction with Jacques Derrida's concept of hauntology. Through a dialogue with the horror genre, and an exploration of the "spectres" of Spanish society, Iñárritu connects the exploitation and suffering of present-day immigrants in Spain with that of exiles of the Spanish Civil War. This correlation between the current Others and the not-so-distant Civil War victims establishes a genealogy between citizen and migrant; dead and undead. By framing the unearthing of the dead and the fates of migrants as family affairs, the film portrays an interconnectedness with the ghosts of the past, and with the marginalized in society. Biutiful deals in both literal and figurative specters. A specter is a ghost, an apparition, or a spirit; but may also be any shadowy figure that provokes unease or fear. "Haces visibles a los invisibles," commented the novelist Jorge Volpi, in an interview with Iñárritu about the film. Indeed, the director deals in ghosts and specters, entwining them around the linchpin Uxbal - a man who is able to talk to the dead. Uxbal is a medium for hire, an intermediary between the living and the dead, but also between the documented and the undocumented. Iñárritu, in line with Derrida, by thus connecting the plight of exiles of the Spanish Civil War with the fate of those living in contemporary society's shadows, calls for a level of justice, social responsibility, and identification with migrants.

Hauntology is introduced in Specters of Marx as a replacement to or even an expansion of ontology, a way of understanding history and being in which voices and deeds of past, present and future dialogue and echo, in concert. Fundamental to hauntology is the figure of the spectre or revenant, who exhorts those in the living present with the voices of the past and the future. The presence of ghosts in Biutiful adds to the ethical weight of the film, for "to hear the injunction of a ghost is to call for responsible action" (DiFrancesco 26). The ghostly figure, spectre, or revenant inhabits a disjointed time with its own logic, as the revenant 
"begins by coming back" (Derrida 11). Ultimately, this disjointed or anachronistic time is necessary for justice, which is not possible without a consciousness of the repercussions of the past, and a responsibility towards the future. Uxbal inhabits this disjointed time, and is one of the few characters in the film able to function within the "logic of haunting," as Derrida describes it (10). Uxbal can communicate with ghosts by listening to their confessions and conveying their thoughts and exhortations in the present. So, too, does he revisit his own family history, specifically the life and death of his father Mateo (Nasser Saleh), an exile during the Spanish Civil War. The father, too, comes to inhabit the present, in the form of documents, photographs, a wedding ring, and, crucially, in the form of his physical presence - his exhumed corpse.

Derrida, in Specters of Marx, exhorts the reader "to learn to live with ghosts ... to live otherwise, and better. No, not better, but more justly. But with them ... And this being-with specters would also be ... a politics of memory, of inheritance, and of generations" (xviii; emphasis in the original). Derrida emphasizes that to live a just life, we must bear responsibility to those who would be considered the victims of history: those who have suffered violence, injustice, and even those who have simply been forgotten. These ghosts or specters are those whom we must to use the language of the vampire tale - invite in. This aleatoric manner of constructing a thoughtful existence permeates Biutiful, as Uxbal seeks to learn to live, as Derrida suggests, from the Other and from imminent death: to put his life in order before he dies. Though he engages in criminal activities, he strives to act in a just manner, to treat migrants humanely in the midst of exploitation and squalor, and prepare himself and his family for his passing on. The moral imperative that imbues Derrida's work permeates the film, as the dead are unearthed; rising into the physical space of the living, as is the case of Uxbal's father, Mateo; or again, as spirits, who speak to Uxbal in confession or reproach. Those other specters - immigrants - further permeate the physical space of contemporary Spain, as the film follows their individual fate and the impact of police violence, deportation, and exploitation on their lives.

SOMETHING IS ROTTEN IN EL RAVAL

The Barcelona of Biutiful is hardly recognizable to those only familiar with touristy images. Instead it is represented as an urban purgatory, with an emphasis on the darker, seedier side. This is a bitter flavour compared to the one Barcelona sells to the world which presents the city as wealthy and cosmopolitan, with playful modernist architecture, and Mediterranean warmth. Much of the film centers around the El Raval neighbourhood, as 
well as the towns of Santa Coloma and Badalona, and their large migrant populations, while the major landmarks of the city, such as the Sagrada Familia, are not shown except briefly, in twilight street scenes where characters are penned in by the buildings. ${ }^{4}$ Instead of stunning panoramas, Iñárritu favours subterranean locations, dark, claustrophobic interiors, and shots of cemeteries; close-ups of dead bodies, insects and fungi, all of which suggest something unclean, murky, even dead or decaying that permeates the city. Iñárritu's insistence in showing the "unadvertised" aspects of the city and refusing to comply with the "official" narrative of Barcelona is manifested in various ways. Celestino Deleyto and Gemma López highlight the unusual use of nationalities and language: Uxbal's daughter Ana is played by Hanaa Bouchaib, the daughter of North African immigrants; the actor who plays his father, Nasser Saleh, is of Moroccan origin. Uxbal does not have a Catalan accent but his brother, Tito (Eduard Fernández) does, while the Catalan language is almost absent from the film which favours Spanish as well as the languages of the migrants who populate the film (168).

The title, Biutiful, a misspelling of the word beautiful, further frames Iñárritu's Other Barcelona. It references a scene in which Ana, working on her English homework, asks Uxbal how to spell the word and he gives her a phonetic spelling. The tensions that arise between a "beautiful" and a "biutiful" city are described by Brad Epps, in the essay "Space in Motion: Barcelona and the Stages of (In)Visibility": "Barcelona's beauty, its vigor and verve is not the whole picture, in no small measure because the whole picture cannot but be fractured, shot through with something less than beautiful, other than beautiful, something that disrupts, complicates, and arguably alters the very sense, or knowledge, of the beautiful" (194). If "beautiful" Barcelona is modern, shiny, wealthy and controlled, "biutiful" Barcelona is, if not its opposite, then its twisted twin of poverty, darkness, distress, and chaos. That both cities - beautiful and biutiful - co-exist, and that, in fact, the latter represents the human cost of the former, is part of the critique that the director mounts of the city.

In a 2010 interview with Manuel Cuéllar, Iñárritu indicated that, by focusing on the lives of immigrants in contemporary Europe, he wished to reflect a reality that many ignore or simply do not wish to see, "una supervivencia que se está llevando a tres minutos de los barrios residenciales más exquisitos de Europa," which teaches us the worst and the best of humankind. The viewer might retort that, for most of the film, we see exclusively the worst of humanity. The gritty realism in the images of shadow and filth is intensified by the callousness of many of its inhabitants. Iñáritu demonstrates directly the exploitation of vulnerable 
workers and the human cost of globalization and capitalist modernity. The director has commented on the critique the film makes of the exploitation that is fueled by globalization and capitalism:

Es intolerable la riqueza extrema acumulada en el primer mundo, en ciertas partes del primer mundo, y por otra parte la gran y extrema pobreza del otro polo, ha creado la necesidad de un movimiento humano inevitable en busca de trabajo y de dignidad. Yo creo que esta película retrata ese desequilibrio, esa injusticia que supone la explotación humana. Es algo que ocurre también en los Estados Unidos, donde yo vivo. El abuso y la utilización de los seres humanos como materia de trabajo desechable. ("Biutiful es")

This lack of equilibrium between society and system is discussed by film theorist Laura Frahm, who frames the city as a metaphorical body that, like Uxbal's own physical body, is out of balance, infected and decaying (149). The instability and corruption are a result of practices in which the human is subordinate to profit and the only language understood by many inhabitants is money. ${ }^{5}$ Uxbal does not understand Hai (Taisheng Chen), the sweatshop owner, or his lover Liwei (Jin Luo) when they speak in Chinese. But when Hai wants to get Uxbal's attention, he makes sure to give him plenty of cash. In the scene where Uxbal bribes the corrupt cop Zanc (Rubén Ochandiano), he is ordered to "speak," meaning, ironically, that talking must cease because it is time to hand over the money (28:44). After an emotional, even tragic, moment between Uxbal and his estranged wife Marambra (Maricel Álvarez), she tearfully proclaims her love for him and they embrace. The tender moment turns tawdry when she asks him if he has any money, not once but twice. The preoccupation with the bottom line, or as the foreman Mendoza (Karra Elejalde) says to Uxbal, "los costes," over any consideration of working conditions, living conditions, or simple human decency, is brutally hammered home by González Iñárritu throughout the film (1:00:46). Perhaps no more so than when the Chinese workers die of asphyxiation, locked into the basement of the icy warehouse due to faulty heaters which Uxbal purchased because they were the cheapest. Uxbal himself profits from his gift as a medium, from the emotional vulnerability of people who want news of their dead loved ones. And, although he tries to help when he is able, he also makes money from the dangerous and illegal work that migrants do in his dealings as a black-market broker. The rough Barcelona depicted is a "frontier zone," in which the inhabitants behave in unpredictable, extreme ways in the quest for both profit and survival (Sassen 67; Azcona 7). 
Cruelty is not just confined to those working in the black market, like Mendoza and Zanc, but extended to other spheres, such as medicine. This is evident from one of the first scenes of the film, when a close-up shows Uxbal's sweating, contorted face as he writhes in pain during a rectal exam. As the camera pans out, the examination ends and the doctor asks Uxbal a series of formulaic questions about symptoms, punctuated with a rather accusatory "you couldn't come sooner?" (3:56). In spite of the invasive, painful exam and suggested possibility that Uxbal's symptoms could mean something grim, the doctor never looks him in the eye, and quickly leaves the room. The nurse who follows is equally detached, until Uxbal reacts violently to the pain of being pricked with the needle. The lack of warmth and humanity shown towards Uxbal is underscored by the fluorescent lights, which cast a cold pall on the faces of the actors, as well as the eerie green color of the room and its clinical coldness, which matches the attitudes of the nurse and doctor. This is contrasted with Uxbal's willingness, even necessity to "be with" and even touch, or caress, what is marginal or low: even that which is literally rotting and dead. Uxbal is himself living in the shadows: he is poor, works on the black market and, as a charnego, ${ }^{6}$ also occupies a subaltern position in Catalonia. In this sense Uxbal is a living manifestation of the border dynamics created within contemporary "global cities," such as Barcelona (Deleyto \& López 168; Azcona 3).

In Uxbal's communications with spirits, he not only speaks to the spirit, as Derrida would have us do, but he also literally holds the dead, in his intent to comprehend and engage. The first time in the film that Uxbal speaks to one of the African migrants with whom he works, he does so by putting his arm around the man, as they converse quietly and covertly. Uxbal's ability to be an intermediary indicates his capacity to recognize what others may not, painful realities of both the past and the present that others would rather forget, bury, or build over. For Derrida, it is "almost impossible ... to speak to the specter, to speak with it, therefore especially to make or to let a spirit speak" (11). The spectator, or one who is a "witness" or "observer," or even an "intellectual" cannot engage, but rather merely look at. In large part this is because spectators, and especially scholars, are bound-up in the binaries of "the real and the unreal, the actual and the inactual, the living and the non-living, being and nonbeing..." (12). Uxbal transgresses these dualities, in his various roles as a medium and intermediary, shuffling between spheres and crossing the borders between those living in the shadows, and those in the light. $\mathrm{He}$ possesses "the singularity of a place of speech, of a place of experience, and of a link of filiation, places and links from which alone one may address 
oneself to the ghost" (Derrida 12). His unique position as a citizen, but also charnego, alive, but able to speak to the dead, allows him to communicate with all.

In Biutiful, it is not the scholar or intellectual per se who cannot engage, but rather those who do not wish either to understand or to confront horrors of both the past and present. This extends, crucially, to the audience, in our role as spectators. This said, Biutiful acts on us, in philosophy scholar Robert Sinnerbrink's words, by creating an "ethical experience" for the viewer; to "disclose, via cinematic means, the complexity of that world in ways that elicit sympathy and understanding while inviting a critical questioning of their alienating conditions of social existence" (170). By the time the film ends, we shall have moved closer to a point of commonality with specters, and seek to understand them. The experience of viewing the film should, in Sinnerbrink's estimation, transform our way of seeing the world, and prompt us to acknowledge "that there is a problem demanding our attention" (171). The style favored by cinematographer Rodrigo Prieto, long-time collaborator of Iñárritu, creates a specific viewing experience in which the audience feels part of the action. Deborah Shaw argues that via Prieto's "free-ranging" handheld camera style, extreme close-ups, whip-pans and editing "viewers are often positioned as if they are in the room or sharing the space of the character and any sense of distance is removed from their look" (149). The result is that we can no longer feign ignorance or indifference because we, like Uxbal, have seen all. The skillful use by the director of the aesthetic conventions of horror facilitates this emotional, visceral effect on the viewer.

HORROR AND SPECTERS

The presence of the supernatural or the uncanny paradoxically intensifies Biutiful's gritty realism by speaking to the reality of death, and even announcing Uxbal's own imminent death in advance. Prieto confirms that he and Iñarritu strove to film the scenes with supernatural activity in as realistic a manner as possible, using the trademark handheld camera, because the metaphysical is a part of Uxbal's daily life. However, there are some moments of digital editing in which we see Uxbal's image or shadows moving more slowly or at a different pace than his physical body. When he is sitting on his bed, packing rolls of cash in order to hide them in his socks, his reflection in the mirror does not follow the movement of his head, but rather gazes back, sadly, at his (unaware) self. These scenes punctuate the progress of his illness, visually dramatizing the fact that he is on the path to 
leaving the physical plane as a part of him begins to split from his dying body.

The gloomy darkness of much of the film, the recurring and graphic presence of cadavers, bodily destruction and painful, even gruesome death, are a nod to the conventions of the horror genre, and are appropriated quite specifically by Iñárritu to signal what is horrifying in modern life: exploitation at the hands of a corrupt system and disregard for human dignity. Biutiful is not classified as a horror film, nor was it marketed as such: in fact, the director himself has called it a tragedy. ${ }^{7}$ But one may engage with the discourse of horror, an incredibly diverse genre, without producing a horror film. Very generally and loosely defined, horror seeks to frighten the audience and to provoke sensations of fear and disgust. While many films feature a monster - either an actual supernatural being or a human who behaves monstrously, as in slasher films - in Biutiful there is none of this. ${ }^{8}$ What is monstrous are the callous ways in which people are exploited and humiliated and the lack of communication beyond straight financial transactions. Another key feature of horror is the threat of death. Not just any death, however, but one marked by terrible suffering, or "what Stephen King sardonically dubbed, 'the bad death"' (Worland 8). Biutiful provokes the audience, eliciting shock or even disgust with dreadful images of suffering, disease, and immigrant exploitation. The "bad death" is present in various moments, and Uxbal himself is a dead-man walking, because he is dying of terminal cancer. The body terrors are evident in the pain and breakdown of his organism, as he urinates blood, vomits on the street, and doubles over in agony at various moments of the film as the cancer progresses. ${ }^{9}$

The techniques used in horror films to achieve their effects have been studied by Brigid Cherry, in her work appropriately titled: Horror. Cherry emphasizes that:

Many of the principal signifying conventions of the horror genre ... are visual and aural ones. These include: lighting codes used in order to create darkness, shadows and obscurity; discordant or unsettling sound effects and musical cues to enhance feelings of suspense, moments of shock or general feelings of unease; monster make-up and other special effects used to depict death and the destruction of the body; editing techniques and cuts which again create suspense or jump moments; and certain camera shots and angles (not the least the point-of-view shot) to suggest danger. (54-55)

On the night of Uxbal's death, Iñárritu employs these techniques to great effect, creating suspense and unease in the viewer as Uxbal is confronted 
with the reality that his death is about to occur. His position at the threshold of death is further dramatized by the change in aspect ratio which occurs in the film, from 1.85 to, eventually, 2.40 when the Chinese bodies wash up on the beach. In a 2011 interview, Prieto explains that the change in aspect ratio represents "ultimate release," as Uxbal accepts death and his lack of control, broadening his view and opening himself up to what comes next. It is twilight, and he is in the bathroom, shooting himself with painkiller in the darkness, which is shown in close-up. Delirous, he hears a noise outside of the bathroom and is frightened. Feeling vulnerable, he calls out to Ige (Diaryatou Daff) asking if it is she. ${ }^{10}$ She assures him that it is, and the camera pans to show her inky shadow on the other side of the bathroom door, in the most literal reference in the film to immigrants as shadows or specters.

Sound is used to great effect in this scene to produce suspense. Initially we hear only the sound of air, but after Ige's shadow passes on the door, the whoosh intensifies, as well as a mechanical ticking and whirring sound and an eerie high-pitched whine, like feedback from a speaker. The whine, together with the even more insistent ticking and piston-like thumping, communicates Uxbal's fear and racing heartbeat as he realizes that his time has run out, because he sees his own spirit walk across the bathroom to the door, an image reflected in the mirror. A close up of his face shows him to be unnerved and shocked. He staggers out of the bathroom, and another close-up with the hand-held camera, blurred and out of focus indicates his disorientation, likely due to the drugs. The whine increases in intensity and volume, reaching a climax when he looks to his left and sees, to his horror, his own spirit floating on the ceiling, head scrunched, hands pressing up trying to escape.

While the cinematic conventions of horror intensify the distress and tragedy of the film, as demonstrated in the bathroom scene, at the same time the supernatural and spiritual facets create a moral and ethical dimension by introducing el más allá, or the "beyond." While there is no "fire and brimstone" judgment passed on the characters, certainly the presence of a realm beyond life, and of the need to be at peace before one can get there, weaves into the film a sense of morality and justice, however ambiguously defined. This is done on several levels, principally through Uxbal's gift as a medium, which allows him to engage characters who cannot pass on until they atone for their wrongdoings, and by following Uxbal's own attempts to put his affairs in order and make amends before he too, dies. This is driven home at various junctures, first represented by the dead owl, which appears at the beginning and end of the film, in the 
peaceful, snowy limbo where Uxbal meets his father - a modern-day Hermes, guiding his son's soul into the beyond.

Uxbal's father and son - both named Mateo - tell the story that an owl spits a hairball out of its beak when it dies. That is to say, a catharsis must be had upon death, and the hairy tangle of matter, of anger, or remorse, must be expelled. While only alluding to Judeo-Christian constructions, the presence of spirits serves to intensify the importance of atonement and of possible consequences for those who do not. Rick Worland indicates that the "affinity for the lesson, often metaphysical, implicitly social" is a main facet of classical horror, which "seem[s] to form a secular, parallel narrative to the essentially religious traditions of the cultures that generate them. Their plots describe situations that carry ultimate consequences" (8). Luis, the dead boy, could not pass on because his guilt about stealing a watch was holding him back. He confessed to Uxbal, and asked for forgiveness, saying that he was very afraid. Uxbal's mentor Bea (Ana Wagener), also a medium, exhorts him to put his affairs in order before he dies - and reminds him that the gift they have should be given for free. When Uxbal confesses to her what has occurred to the Chinese because of the faulty heaters he bought, she consoles him and tells him that he must go to them and ask for their forgiveness. The "'metaphysical' notion of justice" set up by the film speaks to the principle of living a just life, and while this falls outside of the criminal justice system, within the film Uxbal must take responsibility and ask for forgiveness (Sinnerbrink 179). Uxbal, owl-like, must expel the bile of guilt and shame as he prepares himself for death.

Migrants and Historical Memory: A New National Family Haunting and horror are common frameworks for fictional representations of the Civil War and the dictatorship. Employed as strategies to process the very real and horrific atrocities, haunting in particular served to represent metaphorically and suggestively a political point of view during a period of censorship. Jo Labanyi has written eloquently on what she has called "the aesthetics of haunting" and its social and artistic significance ("Memory" 109). Films such as El espiritu de la colmena (Erice 1973), Cría Cuervos (Saura 1975), El espinazo del diablo (del Toro 2001) and novels such as Luna de lobos (Llamazares 1985), Beatus Ille (Muñoz Molina 1986) and $O$ lapis do carpinteiro (Rivas 1998), among others, acknowledge the horror, as opposed to attempting to "sanitize" or explain it away ("Memory" 107). Labanyi argues that these strategies promote an engagement with the past, in the vein of "hauntology," which acknowledges and honors its effect on the present at the same time as it 
works to improve the future ("Memory" II3; "History" 66). Crucially, this contrasts with a desire to break unequivocally from the past and treat it as a relic that has no functional purpose in a system built on capitalist modernity, in which only the new is profitable.

The revenants of Biutiful are not solely the ghosts or spirits who communicate with Uxbal. Rather, those who return also do so in physical form, concretely, the bodies of the dead Chinese who wash up on to the beach, and the disinterred corpse of Uxbal's father Mateo. Uxbal's father was a political exile, who fled to Mexico during the dictatorship because he could not "keep his mouth shut," only to die there of pneumonia. With the unearthing of Mateo and the family discussion of repression and exile that results, the film inserts itself into the Historical Memory debate in a subtle, but powerful manner. Perhaps it is unsurprising that reverberations of the Civil War would appear in an Iñárritu film shot in Spain, as his close friend and collaborator, Guillermo del Toro, had already made two films about the Civil War - El espinazo del diablo and El laberinto del fauno (2006) -

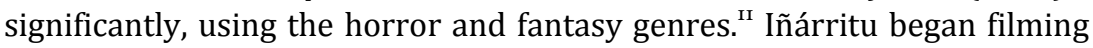
Biutiful in 2008 but spent a year in Barcelona prior to shooting, undertaking a self-described "trabajo periodístico" in order to immerse himself fully in the realities of migrants in Spain, even to the extent of going on two raids with the police ("Biutiful habla"). Yet his time in Spain would have acquainted him as well with the polemical national discussion on justice for victims of the Civil War. In December, 2007 the Ley de Memoria Histórica came into effect. ${ }^{\mathrm{I2}}$ The law, which condemns the Franco regime, was preceded by years of acrimonious public debate about the national representation and interpretation of the Civil War and the dictatorship (Boyd; Labanyi, "The Politics"). Additionally, since 200o, there have been ongoing excavations of mass graves by anthropologists, archaeologists and forensics, collaborating with the Association for the Recovery of Historical Memory (Faber; Ferrándiz). The exhumation of Uxbal's father provides a strong link to the debates on memory and justice in contemporary Spanish society.

Parallels between the situation of current migrants in Spain with that of exiles of the Civil War and dictatorship are established with the two construction sites featured in the film. The cemetery which houses Uxbal's father's coffin is to be demolished in order to build a shopping mall, for which he and Tito will receive money as reparation. The bulldozing of a memory site, demolishing it in order to make way for a new and profitable enterprise, again indicates the rule of money and profit, of a relationship with progress and the future which disengages with the past: “... it is as if money has destroyed the memory of previous generations ... it gets rid of 
history which is not rentable, and transforms it to the eternal present of production and consumption" (Beilin 14). The second construction site is one in which both Uxbal and Tito broker an under-the-table deal to hire undocumented Chinese workers instead of union contractors. In both instances - the cemetery and the building site - Tito is interested in a quick transaction and the money received. While he is not interested in involving himself in the workers' labor conditions, Uxbal on the other hand argues with the foreman of the site to ensure a better pay rate for them. At the grave Uxbal asks to see the remains of his father, and takes possession of his final belongings. In contrast, Tito's contribution is to suggest that they combine the ashes of their father with those of their mother, so they do not have to spend money on a second urn. Uxbal is more outwardly affected by the experience, and wants to engage and touch his father before the body is cremated. The brothers represent two ways of dealing with the past, and with painful memories: Tito wishes to focus on the new and profitable, Uxbal, on the other hand, engages with the past. This knowledge expands his thinking in the present, becoming a part of his and his children's identities.

Uxbal's encounter with his father at the Monjuic crematorium is an ironic scene, contrasting a sentimental, nostalgic piano waltz with the macabre image of a mummified cadaver. While Tito flees in disgust at the sight and smells, Uxbal approaches his father with an expression of wonder, even innocence. The body is well-preserved, having been embalmed and enclosed in zinc. The close-ups emphasize the grotesque cadaver's disintegrating, cracked flesh, some of which seems to have holes in it, and the embalming material collected like spiders webs on the mouth. The state of the cadaver alludes, obliquely, to zombie resurrection due to its abject state: dead but lifelike, seemingly ready to sit up and protest "how could you have forgotten me?" The melancholy, yet beautiful, music conveys Uxbal's emotional state as he meets his father for the first time, weeping and seemingly unfazed by the hideous state of the body, as he recognizes his own imminent fate. Through the music and Uxbal's reaction, the scene is turned into a touching, even cathartic, one, instead of being merely horrific.

The importance of memory and of incorporating those who are not here into the life of the family, acquires a special poignancy with reconciliation, and recognition at Monjuic. Uxbal, who never knew his father and can barely remember his mother, is afraid of being forgotten by his own children, and begs Ana to remember him after he is gone. Uxbal is able to mourn his father and honour his memory by introducing him into the family sphere, specifically through his final possessions: photos, his 
marriage registry and an engagement ring. Uxbal gives the ring to Ana just before his death, in the scene that begins and ends the movie. The ring is imbued with significance because of the connection between his parents and their love, and it was also the ring that he gave to Marambra. Ana comments that her mother always said that it was "de mentira," or fake, not even wearing it on her ring finger. Marambra, like Tito, cannot appreciate the deeper significance of the object. For her, its authenticity lies in whether or not it is a real diamond, and is related to its market value as opposed to its intrinsic or symbolic one. Labanyi argues that "photographs, like film stills, play an important role as images of a fragmentary, discontinuous, spectral past" ("History" 69). However, in Biutiful, the spectral ceases to be merely distant and disjointed, as the photographs, the ring, and the anagnorisis that occurs at Monjuic are opportunities in which the specters are reintroduced into the present, providing an opportunity for explanation, just as a forgotten and obscure past recovers vitality and meaning.

The filming of Biutiful began in October 2008, the same month in which controversy erupted as Judge Baltasar Garzón accused Franco and more than thirty former generals and ministers of crimes against humanity (Yoldi; Ferrándiz 319). He also ordered exhumations to begin at 19 mass grave sites. José Colmeiro argues that the controversy regarding historical memory and justice is a "reawakening" on the part of Spanish society:

A result of social, judicial, and political movements reclaiming the unearthing, literarily and symbolically, of the past (the atrocities and human rights violations committed during the Civil War and its aftermath). ... Thousands of unmarked burial sites in ditches along the roads still remain in the Spanish landscape, invisible but ever present, just like ghosts still awaiting their day of justice. The luminal [sic] and invisible position is an adequate metaphor of their non-existing status in the margins of the official history... memory has now come back to the center stage in discussions about what to do collectively with that past, with crucial political, legal and ethical repercussions. (28)

In Biutiful, Iñárritu responds to this reawakening, this movement for justice in Spain; the marginal is no longer permitted to be buried or hidden from the eyes and consciousness of the spectator. The sea returns the dead Chinese to the shore, refusing to conceal their bodies in its deepest depths, and as a result their story is broadcast on the news and action is taken. The unearthing of Mateo was painful for Uxbal, but ultimately cathartic, and he was able to "meet" and bury his father in a manner which honours his memory, telling the tale of his exile and death to his grandchildren. And 
Ige, instead of remaining an outsider, or an Other who had a run of bad luck, moves in with Uxbal and his children, assuming a role of caretaker and surrogate mother.

The fates of Uxbal and Ige's families establish a connection between current migrants and the victims of the Spanish civil war, linking Spaniards with immigrants via their own recent migration history. Uxbal's father was a political exile who died abroad, leaving his children and wife in precarious circumstances. Ige's husband, Ekweme (Cheikh Ndiaye), is deported, returning to Senegal leaving Ige and their baby Samuel alone in Spain. Uxbal himself is about to cross a border, not as an exile or migrant, but the ultimate border: that between life and death. These connections are intensified as Ige and baby Samuel become a part of Uxbal's family sphere. In spite of her dire situation after Ekweme is deported, she still tries to maintain her dignity and independence, initially refusing to take any money that Uxbal offers her. When Uxbal moves into Marambra's apartment with Ana and Mateo, he lets Ige and Samuel live in his place, with the rent already paid for several months: thus, finally offering something of himself for free. The situation with Marambra proves to be untenable, so Uxbal, Ana and Mateo move back into their house, this time with Ige and Samuel. Convivencia is awkward, intitally, and Ana and Mateo are suspicious of the stranger whose crying baby keeps them awake at night. This is dramatized when Ige first picks them up from school, and the children walk on the opposite side of the street, looking at her warily. Eventually she joins them, smiling, and they seem to relax. This is followed by a series of extreme close-ups of Ige, Mateo, Samuel and Ana, in the domestic space. The close-ups elicit a feeling of identification between the audience and the characters, fixing our gaze on theirs, but also serve to identify the children with Ige and place her as a member of the family, as she treats a cut on Mateo's face left from when Marambra hit him. Her calm kindness contrasts with Marambra's erratic, sometimes violent behavior.

Ige does not only take care of the children, but also Uxbal. As his health rapidly declines, Ige helps him take medicine and even feeds him. Her careful, gentle manner again provokes a contrast, this time with the nurse who roughly tried to draw Uxbal's blood at the beginning of the film. Uxbal begs her to stay on after he dies, giving her all the money he has saved and asking her to take care of his children. She is reluctant and almost leaves Spain with the money in order to be reunited with Ekweme in Senegal but she seems to change her mind and return to the apartment, giving the lie to Zanc's warning that Uxbal should not trust a man who is hungry. Ige's role is not unproblematic because it may evoke stereotypes of female migrants as domestic servants, specifically, African women as 
subordinate caregivers. However, within the moral framework of the film, Ige, unlike Marambra and Tito, is clearly imbued with a sense of responsibility for others, and for the dignity of their lives. In other words: to living a just life.

The final touching scene, a "mirror" of the first scene of the movie, shows Uxbal's death and his quiet acceptance. The scene repeats the dialogue from the beginning of the movie, but this time instead of a closeup of Ana and Uxbal's entwined hands, the camera pans over them as they lie together in the bed. Uxbal bequeaths his mother's ring to Ana, and passes on. While his death is tragic, it is not horrific, for although he loses his daughter and son, he reunites with his father in the peaceful, snowy woods. Iñárritu offers the audience moments of caring, love and encounters with the dead, with specters, that serve as an antidote to, or at least may temper, the horror. These moments, however fleeting or imperfect, occur within the domestic sphere and around past and future family bonds. The family ties are extended to incorporate individuals not blood-related, specifically, the maternal figures of Ige and Bea. It is in these filial relationships that the director links historical memory of the Civil War atrocities with current migrants.

The family circle that closes Biutiful is an antidote to the horror of exploitation and to the bulldozing of the past, whether it is grandfathers who were exiled due to political persecution, or those political and economic refugees now living in Barcelona. The historical memory debate, and subsequent demand for justice on behalf of the victims and exiles of the Civil War, is a powerful foil to the current situation of immigrants in Spain. If Spanish society would recognize the atrocities of the Civil War, the director suggests, it cannot ignore the extreme circumstances of exiles and migrants living there now. The emphasis on a deeper connection to migrants by placing them, past and present, within the domestic sphere, echoes Derrida's exordium that we can only learn to live from the other, and from death (xvii). Biutiful presents a new national family of sorts, one in which migrants are "let in" hospitably, and invited to take part, between birth and death, in the memory of the past and the challenges of the present.

Western Oregon University 


\section{NOTES}

1 Since Birdman the director has preferred to be known as Alejandro G. Iñárritu (Screen International). Thus, for the rest of the essay, I refer to him as Iñárritu, but his name appears as González Iñárritu in the Works Cited.

2 See Smith for further discussion of the documentary-style cinematography of Amores Perros, as well as Iñárritu's focus on class conflict.

3 William Lansing Brown also notes the themes of redemption through violence and suffering.

4 See Fraser for a detailed analysis of Barcelona as a setting and even "coprotagonist" of the film.

5 Daniel Garrett, in his review of the film, also discusses the centrality of money to Biutiful, and the space that the film carves out for the spiritual or "inner life,' which is more precious than material goods, which we will lose.

6 A charnego, or in Catalán, xarnego, is a derogatory word to refer to a Spanish immigrant to Catalonia from a non-Catalan region, or the children of those non-Catalan migrants. The word rose to prominence during the mass migrations of rural working-class and poor citizens from various regions during the 196os (Vilarós 232). While Uxbal is ostensibly from the region, he is the child of non-Catalan migrants, therefore lacking a "pure" Catalan origin story. Iñárritu refers to Uxbal as a charnego in his essay on the film for the Cannes Film Festival.

7 “Si tuviera que etiquetar la película en un género, este sería el de la tragedia clásica. Es la caída libre de un hombre" ("Bitufiul es").

8 Jancovich discusses the horror genre more completely.

9 Rabassó also acknowledges the macabre images and the theme of death in Biutiful.

10 The audience never actually sees Ige return, and although we hear her voice the film never reveals whether or not Ige truly did come back or if her presence is a hallucination of a dying man. My interpretation is that she does, indeed, return.

"Iñárritu, del Toro, and Alfonso Cuarón are known as "los tres mosqueteros" in Mexico, and "the three amigos" in the US. Together they own the production company Cha Cha Cha. (Shaw 2-3).

12 While it is commonly known as the Ley de Memoria Histórica, the full name is: "Ley 52/2007, de 26 de diciembre, por la que se reconocen y amplían derechos y se establecen medidas en favor de quienes padecieron persecución o violencia durante la guerra civil y la dictadura." 
WORKS CITED

21 Grams. Dir. Alejandro González Iñárritu. Estados Unidos. Prod. This Is That, Y Productions, Mediana Productions. 2003.

Amores Perros. Dir. Alejandro González Iñárritu. México. Prod. Altavista Films, Zeta Film. 2000.

AZCONA, MARÍ A D. M. "“We Are All Uxbal”: Narrative Complexity in the Urban Borderlands in Biutiful." Journal of Film and Video 67.1 (2015): 3-13.

Babel. Dir. Alejandro González Iñárritu. Estados Unidos, Japón, México. Prod. Paramount Pictues. 2006.

Beilin, katarzyna. "Die and Laugh in the Anthropocene: Disquieting Realism and Dark Humor in Biutiful and Nocilla Experience." Forthcoming paper in Hispanic Issues. 2015.

Birdman: Or (The Unexpected Virture of Ignorance). Dir. Alejandro González Iñárritu. Estados Unidos. Prod. New Regency Features. 2014.

Biutiful. Dir. Alejandro González Iñárritu. España. Prod. Menagatroz, Mod Producciones, Focus Features. 2011.

B OYD, CAROLYN. "The Politics of History and Memory in Democratic Spain." The Annals of the American Academy of Political and Social Science 617.1 (2008): 133148.

CHANG, J US Tin. “Biutiful.” Variety 17 May 2010. N.p.

CHERRY, BRIGID. Horror. London: Routledge, 2009.

colmeiro, José. "A Nation of Ghosts?: Haunting, Historical Memory and Forgetting in Post-Franco Spain." $42^{\circ} \mathrm{F}$ : Journal of Literary Theory and Comparative Literature 4 (2011): 17-34.

Cría Cuervos. Dir. Carlos Saura. España. Prod. Elías Querejeta. 1976.

DEL L T O, C E LE ST I N O, A D M AR I A M. AZ Con A. Alejandro González Iñárritu. Urbana: U of Illinois $\mathrm{P}, 2010$.

deleyto, celestino, And Gemma lópez. "Catalan Beauty and the Transnational Beast: Barcelona on the Screen.” Transnational Cinemas 3.2 (2012): 157-175.

DE L GA D O, MARí A. "Biutiful." Sight and Sound 21.2 (2011): 48-49.

DERRIDA, JACQUES. Spectres of Marx: The State of the Debt, the Work of Mourning and the New International. New York: Routledge, 1994.

D I F A N C E S C 0, M A R I A. "Facing the Specter of Immigration in Biutiful." Symposium: a Quarterly Journal in Modern Literatures 69.1 (2015): 25-37.

EPPS, B RA D. "Space in Motion: Barcelona and the Stages of (In)Visibility." Arizona Journal of Hispanic Cultural Studies 6 (2002): 193-204.

El espinazo del diablo. Dir. Guillermo del Toro. España. Prod. El Deseo, Tequila Gang, Sogepaq. 2001.

El espíritu de la colmena. Dir. Víctor Erice. España. Prod. Elías Querejeta. 1973. 
FABER, SEBAStiAan. "An Underground Landscape of Terror: Anthropologist Francisco Ferrándiz on Spain's Civil War Exhumations." The Volunteer 32.2 (2015): 5-8.

FERRÁ ND I Z, FRA NCI SC 0. "The Intimacy of Defeat: Exhumations in Contemporary Spain." Unearthing Franco's Legacy: Mass Graves and the Recovery of Historical Memory in Spain. Ed. Carlos Jerez- Farrán and Samuel Amago. Notre Dame: U of Notre Dame P, 2010. 304-325.

FLES LER, DANiE LA. The Return of the Moor: Spanish Responses to Contemporary Moroccan immigration. West Lafayette: Purdue UP, 2008.

Frahm, Laura. "Biutiful or the Urban Conditions of a Forced Flexible Mobility." Transfers 1.2 (2011): 146-150.

FRASER, BE N JA m I . “A Biutiful City: Alejandro González Iñárritu's Filmic Critique of the 'Barcelona Model."' Studies in Hispanic Cinemas 9.1 (2012): 19-34.

GARRETT, DANIEL. "Not Beautiful but Brutal: Ugly Facts and Transcendence in Iñarritu's Film Biutiful." Offscreen 15.9 (2011). N.p.

G O Z ZÁ LE Z I ÑÁ RR I TU, A L EJA N D R. "Alejandro G. Iñárritu, Birdman.” Interview by Jeremy Kay. ScreenDaily.com. Screen International. 18 Jan. 2015. N.p.

—. "Biutiful habla de la conquista de España por los inmigrantes." El País. Interview by Jorge Volpi. El País 3 Dec. 2010. N.p.

—. "Biutiful es un vómito espiritual." Interview by Manuel Cuéllar. El País 3 Aug. 2010. N.p.

—. "On Biutiful." Festival de Cannes 14 May 2010. N.p.

JAN COVICH, MARK, ED. Horror, the Film Reader. New York: Routledge, 2002.

lab Any , Jo. "History and Hauntology; or, What Does One Do with the Ghosts of the Past? Reflections on Spanish Film and Fiction of the Post-Franco Period." Disremembering the Dictatorship: the Politics of Memory in the Spanish Transition to Democracy. Ed. Joan Ramón Resina. Atlanta: Rodopi, 2000.

—. "Memory and Modernity in Democratic Spain: The Difficulty of Coming to Terms with the Spanish Civil War." Poetics Today 28.1 (2007): 89-116.

-. "The Politics of Memory in Contemporary Spain." Journal of Spanish Cultural Studies 9.2 (2008): 119-125.

El laberinto del Fauno. Dir. Guillermo del Toro. España. Prod. Estudios Picasso, Tequila Gang. 2006.

LAN I I G B ROWN, WI L Li Am. “Alejandro González Iñárritu’s Biutiful: Resistance, Rebellion, and Redemption In the Depiction of Barcelona's Grim Underworld." Con-textos 22.45 (2010): 141-146.

Llamazares, JUlio. Luna de lobos. Barcelona: Seix Barral, 1985.

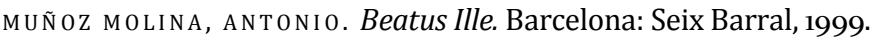
Priet 0, R O D R g o. "Letting Go." American Cinematographer 92.1 (2011). N.p. RIVAS, MANUEL. O lapis do carpinteiro. Vigo: Gerais, 1998. 
RABASS Ó, FRANCISCO JAVIER. "Sadisme, érotisme macabre et oppression: de Los olvidados (Pitié pour eux) de Luis Buñuel à Biutiful d'Alejandro González Iñarritu. " Imaginaires de l'érotisme en Amérique latine: Érotiques / Ésthétiques. Eds. Françoise Aubès and Florence Olivier. Paris: Presses Sorbonne Nouvelle, 2014. 147-156.

SASSEN, SAS KIA. "When the Center No Longer Holds: Cities as Frontier Zones." Cities 34 (2013): 67-70.

SHAW, D в в о A н. The Three Amigos: The Transnational Filmmaking of Guillermo del Toro, Alejandro González Iñárritu, and Alfonso Cuarón. Manchester: Manchester $\mathrm{UP}, 2013$.

Sinnerbin K, RоBert. "Postsecular Ethics: The Case of Iñárritu's Biutiful." Religion in Contemporary European Cinema: The Postsecular Constellation. Ed. Costica Braddatan and Camil Ungureanu. New York: Routledge, 2014. 166-185. Smit h, PAUl J. Amores Perros. London: BFI Pub, 2003.

VIDALES, RAQUEL. "La salida acelerada de españoles al extranjero hace caer la población." El País 15 Oct. 2012. N.p.

VILAR ó S, TERESA M. "The Passing of the Xarnego-Immigrant: Post-Nationalism and the Ideologies of Assimilation in Catalonia." Arizona Journal of Hispanic Cultural Studies 7 (2003): 229-246.

worla n D, Ri c k. The Horror Film: An Introduction. Malden: Blackwell, 2007. Y OLD I, J osé. "Garzón atribuye a Franco un plan de exterminio sistemático de los 'rojos."' El País 17 Oct. 2008. N.p. 